\title{
Acknowledgments
}

\section{PLANNING COMMITTEE}

Anna Gilmore, Jim Thrasher, Joanna Cohen, Joaquin Barnoya, Judith Mackay, Ken Warner, Lisa Henriksen, Luz-Miriam Reynales, Marita Hefler, Nuntavern (Toi) Vichit-Nadakan, Raglan Maddox, Raphael Lencucha, Rich O’Connor, Rima Nakkash, Ruth Malone, Sarah Durkin, Sarah Hill

\section{GUEST EDITORS}

Patricia A McDaniel, Elizabeth Smith

Special thanks to Dr Alan Blum and the Center for the Study of Tobacco and Society at the University of Alabama, and Dr Pamela Ling and Kathleen Franklin of the University of California, San Francisco Center for Tobacco Control Research and Education for assistance with obtaining archival cover images

\section{FUNDING}

Check for updates

This project has been funded in whole or in part with Federal funds from the National Cancer InstiTo cite: Tob Control tute, National Institutes
HHSN261201700004I

(c) Author(s) (or their employer(s)) 2022. No commercial re-use. See rights and permissions. Published by BMJ. 